\title{
Balancing resources, demand, new challenges, and risks: what is next for the coal industry of Kuzbass
}

\author{
Yuri Fridman ${ }^{1,2^{*}}$, Galina Rechko ${ }^{1,2}$, Ekaterina Loginova $^{1}$, and Alexander Pimonov ${ }^{1,2}$ \\ ${ }^{1}$ Institute of Economics and Industrial Engineering of the Siberian Branch of the Russian Academy of \\ Sciences, 630090 Novosibirsk, 17 Acad. Lavrentyev Av., Russian Federation \\ ${ }^{2}$ T.F. Gorbachev Kuzbass State Technical University, 650000 Kemerovo, 28 Vesennyaya st., Russian \\ Federation
}

\begin{abstract}
The article gives an overview of the main external and internal challenges currently facing the coal industry and thus defining where the economy of Kemerovo Oblast - Kuzbass (a key coal-mining center in Russia) is heading. We claim the fourth energy transition as the most important among such challenges, whose basic paradigm is global economic and, in particular, energy systems decarbonization. Countries striving for a low-carbon economy chose coal as their primary target; for instance, Western Europe expects to exit coal-fired power generation by 2030-2035. Experts do not rule out that the world coal market will depend on China and India, the two emerging economies, in the foreseeable future. In this regard, the competitiveness of its coal products compared to solid fuel producers from Eastern Siberia and the Far East is becoming very important for Kuzbass: rivals are ready to supply higher-quality and logistically less expensive coal to the Asia-Pacific markets. In view of the fact that the idea of creating a coal-chemical cluster in Kemerovo Oblast as a long-term driver for the region's economy has turned out to be untenable, it is now up against the task of forming a new economic doctrine of relations between the coal industry and Kuzbass. We believe it should rest upon the following idea: resources (including coal) have an enormous social and economic value. However, it is only possible to exercise this idea on the principles of harmonized development.
\end{abstract}

\section{Introduction}

Kemerovo Oblast - Kuzbass has practically no competitive advantages outside the system that can be described with the following formula: coal reserves + relatively efficient coal mining and primary processing technologies + supply logistics to major world markets + government support for coal exports. From the point of view of the regional development model that has been built for over two decades, "if we take coal out now, everything will fall apart like a house of cards." And still, as the same twenty years have shown, the growth of coal mining does not lead to Kuzbass' accelerated development. This only ensures the

\footnotetext{
${ }^{*}$ Corresponding author: yurifridman@mail.ru
} 
region's economy is safe and sound $[1,2]$. It is unfortunate that the authorities' loyalty to coal does not mitigate external shocks. The problem is Russian (and Kuzbass as well) coal business being in a figurative perfect storm and experiencing pressure from several internal and external disadvantages simultaneously, which significantly increases their cumulative negative effect on the industry. This situation casts doubt on whether coal will remain the mainstay of the Kemerovo Oblast economy.

\section{Results and Discussion}

The list of unfavorable factors currently having an effect on the coal industry at large is quite extensive. Kuzbass' share in the total coal exports from Russia, the third-largest supplier of this fuel to the global market, is estimated at 65\% (2020) [3]. Naturally, the region feels the impact in full. Let us highlight the key factors.

Factor 1. The world is experiencing a decrease in energy consumption and prices for fossil fuels due to economic slowdown (caused by the COVID-19 pandemic), more efficient energy use (advanced technology), and rapidly growing renewable energy sources (renewables, or RES). Humanity has entered the fourth energy transition, whose basic paradigm is global economic and, in particular, energy systems decarbonization [4, 5].

Factor 2. Among other hydrocarbon resources, coal is the primary target for the reduction of carbon dioxide emissions worldwide. Western European countries expect to exit coal-fired power generation first by 2030-2035, and the United States appeal to everyone to abandon this practice.

Factor 3. Coal suppliers are already feeling the pressure of global financial corporations refusing to fund coal projects, which has led to fossil fuel divestment. More and more, investors are basing their decisions on a company's ESG standing in international ratings that reflect the proportion of companies in businesses with $\mathrm{CO}_{2}$ emissions, including coal mining and coal-fired power generation. Russia's financial market also seeks to comply with global trends.

Factor 4. Over the span of three to seven years, there will likely appear a carbon tax to reduce the efficiency of coal exports. In particular, the European Union is discussing plans to introduce the so-called carbon border adjustment mechanism (CBAM), a tax on emission-intensive imported goods. Such a change will be a severe challenge for Russian exporters, as they consider the EU market quite important.

Factor 5. A sanctions regime may be invoked to curb coal exports from Russia.

Very few experts by now dispute the decarbonization trends; the speed of these processes in different countries continues to be discussed. In the next 15-20 years, the basis for the relationship between renewables and fossil fuels will clearly not be the "either-or" principle but rather the "both-and" logic. Europe will abandon hydrocarbons much slower than is predicted, and Asia will not even start the active phase until 2030-2040. Green energy still poses many unresolved problems (e.g., wind and solar energy accumulation and storage). Resolving them is not only a matter of investment; it is a matter of time.

However, we should not see as viable some experts' POVs that the West and the East alike will still depend on coal-fired plants for a while, or that there are technologies for burning coal without $\mathrm{CO}_{2}$ emissions. Nothing can stop Europe from giving up this fuel, e.g., Germany has adopted a law on phasing out the power generated from brown and hard coal by 2038. China will begin to cut coal consumption starting in 2026. So, while the East will continue coal-fired power generation for several more decades, the competition for Eastern markets will greatly increase.

We assume there is a high probability that global coal prices will not be tied to oil and gas but dictated by two countries, China and India (for instance, in February 2021, the Chinese authorities decided to increase the number of working days for coal producers. As 
a result, prices for Russian steam coal dropped by $\$ 10$ per ton on FOB Nakhodka terms, with oil and natural gas prices going up at the same time). Demand for coal may thus even grow (even more so relative to the fall in 2019-2020), and coal prices might rise for a short time. However, these changes are unlikely to affect coal mining profit margins.

Let us mention several considerations tied to building relations within the coal business-region system that we feel to be important for Kuzbass. The first is internal competition for Chinese and Indian markets among major coal-producing companies in Eastern Siberia and the Far East. For example, A-Property plans to increase coal production at the Elginsky coal mine (Yakutia) by 2023, up to 45 million tons per year, by investing nearly 130 billion rubles. AEON Corporation is to produce up to 10 million tons of coal on the Taimyr Peninsula by 2030. The development strategy of Kolmar (Yakutia) envisages increasing production to 22 million tons by 2022; the producer also aims to expand exports to the Asia-Pacific region.

To sum it up, by 2030, the east and north of Russia will produce not less than 100 million tons of export coal, highly competitive in terms of quality and transport logistics. It should be noted that unlike in Kuzbass, a considerable number of companies extracting coal in Eastern Siberia and the Far East are partially government-owned. Exporting Kuzbass coal from the southern transport corridor in the Azov-Black Sea Basin may reduce the need to convey the fuel to eastern ports, but this will not solve the problem if exports are increased.

The second crucial aspect is the decreasing efficiency of Kuzbass coal reserves! The deposits still carry great potential measured in virgin coal tons. But their marketable coal capacity is much, much less. Firstly, the best mines are long empty. Secondly, the ready reserves are significantly worse in quality and more expensive in terms of extraction technologies.

The third point is the Clean Coal - Green Kuzbass program, along with the Russian President's instruction to invest part of the export proceeds in non-coal assets. These both will substantially increase expenses and reduce the competitiveness of the Kuzbass coal business. The struggle to bring costs down may have an adverse result: even the notion of coal mining as a socially oriented business, which is very conditional today, might get wiped out.

The situation being what it is, some institutions are already making forecasts (e.g., the Energy Research Institute of the Russian Academy of Sciences) that coal production in Kuzbass will have decreased to 197 million tons by 2035 [6].

The fourth issue that deserves attention is the practical failure to create a coal-chemical cluster in Kuzbass as a large coal consumer, coal production driver, and a general driver of long-term regional economic growth [7]. The problem lies in business and the government's lack of interest in this industry. Coal as a raw material loses to oil and gas when competing on the open market. In 10 to 15 years, we can expect from Kemerovo Oblast only a complex of science-intensive enterprises to have low- and medium-tonnage production of coal-derived chemicals, at most. Whether the region will manage to take advantage of the multiplicative effect, which such a complex potentially has, is a different story.

The fifth factor is directly related to the effectiveness of interaction between the coal business and the region: The later the Kuzbass authorities understand the inevitability of transforming the coal industry from a systemically important industry into a sustainably developing one, the more painful this process will be. 


\section{Conclusion}

As can be seen from the above, external and internal shocks, both existing and expected in the near or more distant future, will not allow the coal industry to serve as a driver of accelerated development in Kemerovo Oblast. Instead, they will undoubtedly be an important, if not dominant, factor in the regional economic sustainability for at least another 15-20 years [8, 9]. The region, however, should start to prepare for the declining importance of coal: coal incomes will gradually be replaced by income from other sectors, including those that will emerge and grow because of "coal money" investments. Today, Kuzbass (its authorities, business, and residents alike) faces the need to form a new economic doctrine of relations between the region and its primary industry. It should rest upon the idea that resources (including coal) have an enormous social and economic value, which can only be exercised on the principles of harmonized development [10-13]. The coal industry should try to take on the role of a transformer for the Kuzbass economy. The world has accumulated experience and gained a proverbial toolset for solving the issues of economic diversification, retraining, and migration management [14-18]. Kemerovo Oblast should use it consciously, adapting international best practices to local conditions.

The research was carried out with the plan of research work of IEIE SB RAS, project "Driving forces and mechanisms of cooperation and integration processes in the economy of Siberia" (№ 121040100279-5).

\section{References}

1. V.A. Kryukov, Yu.A. Fridman, G.N. Rechko, E.Yu. Loginova, Kuzbass in a New Age (IEIE SB RAS, Novosibirsk, 2020)

2. Yu. Fridman, G. Rechko, A. Pimonov, Reg. Res. Russ., 7, 333 (2017)

3. I.G. Tarazanov, D.A. Gubanov, Coal J., 3, 27 (2021)

4. V. Smil, Energy Transitions: History, Requirements, Prospects (Praeger, Santa Barbara, 2010)

5. A.A. Makarov, T.A. Mitrova, V.A. Kulagin Global and Russian Energy Outlook 2019 / ed. (ERI RAS - MSM Skolkovo, Moscow, 2019)

6. Yu.A. Plakitkin, L.S. Plakitkina, K.I. Dyachenko, J. Mining, 10, 54 (2020)

7. V.A. Kryukov, Yu.A. Fridman, V.M. Markova, G.N. Rechko, E.Yu. Loginova, IOP Conference Series: J. of Phys., 1749, 012043 (2021)

8. Y. Fridman, E. Loginova, G. Rechko, E3S Web of Conferences, 134, 03002 (2019)

9. Y. Fridman, G. Rechko, E. Loginova, E3S Web of Conferences, 174, 04038 (2020)

10. V. Kryukov, A. Sevastyanova, A. Tokarev, V. Shmat, Econ. Reg., 13, 93 (2017)

11. Yu.A. Fridman, G.N. Rechko, E.Yu. Loginova, Reg. Res. Russ., 10, 467 (2020)

12. V. Kondrat'ev, World Economy Int. Relat., 60, 41 (2016)

13. Yu.A. Fridman, G.N. Rechko, E.Yu. Loginova, World Econ. Manage., 19, 89 (2019)

14. F. Giarratani, D. Houston, Urban Stud., 26, 549 (1989)

15. Regional Structural Change and Industrial Policy in International Perspective: United States, Great Britain, France, Federal Republic of Germany / ed. J.J. Hesse (Nomos, Baden-Baden, 1988)

16. D. Ferranti, G.E. Perry, D. Lederman, W.E. Maloney, From Natural Resources to the Knowledge Economy (World Bank, Washington, 2002)

17. P.Yu. Oei, H. Hermann, Ph. Herpich, O. Holtemoller, B. Lunenburger, Ch. Schult, Energy, 196, 117004 (2020)

18. S. Ville, O. Wicken, Ind. Corp. Change, 22, 1341 (2013) 